\title{
ANALISIS FAKTOR PRODUKSI YANG MEMPENGARUHI PRODUKSI KOPRA DI KECAMATAN TOMOHON BARAT
}

\author{
Karouw Randy Alfredts Zwingly \\ Tommy F. Lolowang \\ Lyndon R. J. Pangemanan
}

\begin{abstract}
This study aims to: (1) identify production factors that influence copra production and (2) analyze the elasticity of copra production factors from copra-producing farmers in West Tomohon District. This research was conducted from January to April 2017. The data used were primary data obtained by survey methods through direct observation and interviews with copra farmers. Data were analyzed using Cobb-Douglas production function. The results showed that (1) factors of production of planting area, plant population, outpouring of labor, amount of equipment, and experience used by copra-producing farmers in Tomohon Barat Sub-district jointly affected copra production but separately influential production factors real and positive for copra production, namely planting area, plant population, and outpouring of labor. Based on the scale of results which show increasing return to scale indicates that farmers are still able to obtain profitable production from a number of added production factors. (2) Based on the level of elasticity of production factors that are positive and more than one. This indicates that the use of planted area production factors, plant populations, and labor has not been efficient because it has not reached maximum profit. Each addition of the production factor resulted in an increase in copra production which continued to increase, while the use of production factors the number of equipment and experience showed a negative value indicating that the use of production factors is inefficient because the production will produce less copra even though the use of production factors is more. *jnkd*.
\end{abstract}

Keywords: Analysis, Copra, Cobb-Douglas production function, West Tomohon Sub-District

\begin{abstract}
ABSTRAK
Penelitian ini bertujuan untuk mengidentifikasi faktor - faktor produksi yang mempengaruhi produksi Kopra dan menganalisa elastisitas faktor produksi Kopra dari para petani penghasil Kopra yang berada di Kecamatan Tomohon Barat. Hasil penelitian menunjukkan bahwa faktor - faktor produksi luas tanam, populasi tanaman, curahan tenaga kerja, jumlah peralatan, dan pengalaman yang digunakan oleh petani penghasil Kopra di Kecamatan Tomohon Barat secara bersama-sama mempengaruhi produksi Kopra, namun secara terpisah faktor produksi yang berpengaruh nyata dan positif terhadap produksi Kopra yaitu luas tanam, populasi tanaman, dan curahan tenaga kerja. Berdasarkan Skala hasil yang menunjukkan increasing return to scale menandakan bahwa petani masih mampu memperoleh produksi yang menguntungkan dari sejumlah faktor produksi yang ditambahkan. Berdasarkan tingkat elastisitas faktor produksi yang bernilai positif dan lebih dari satu, menandakan penggunaan faktor produksi luas tanam, populasi tanaman, dan tenaga kerja belum efisien, karena belum mencapai keuntungan maksimum. Setiap penambahan faktor produksi tersebut mengakibatkan kenaikan produksi Kopra yang terus bertambah, sedangkan penggunaan faktor produksi jumlah peralatan dan pengalaman menunjukkan bernilai negatif, ini menandakan penggunaan faktor produksi tidak efisien (irrasional) karena produksi yang diperoleh akan menghasilkan Kopra yang lebih sedikit dari penggunaan faktor produksi yang lebih banyak.
\end{abstract}

Kata kunci: faktor produksi, produksi kopra, Kecamatan Tomohon Barat

Agrisosioekonomi:

Jurnal Transdisiplin Pertanian (Budidaya Tanaman, Perkebunan, Kehutanan, Peternakan, Perikanan), Sosial dan Ekonomi 


\section{PENDAHULUAN}

\section{Latar Belakang}

Sulawesi Utara merupakan salah satu Provinsi penghasil kelapa terbesar di Indonesia, sehingga terkenal dengan julukan "Daerah Nyiur Melambai". Hal ini terlihat di berbagai daerah di Sulawesi Utara, perkebunan Kelapa mendominasi sektor pertanian.

Selang waktu tahun 2015-2017 diperoleh data bahwa terjadi penurunan produktivitas kelapa di Sulawesi Utara. Hal tersebut kemungkinan disebabkan luas areal mengalami pengurangan. Salah satu daerah yang berkontribusi terhadap produksi kelapa di Sulawesi Utara yaitu Kota Tomohon. Tabel 1 menunjukkan selang waktu tahun 2013 - 2015 produktivitas kelapa berfluktuatif dari $322 \mathrm{~kg} / \mathrm{ha}$ pada tahun 2013 mengalami penurunan menjadi $153,64 \mathrm{~kg} / \mathrm{ha}$ pada tahun 2014, dan kembali meningkat pada tahun 2015 menjadi $298,88 \mathrm{~kg} / \mathrm{ha}$.

Tabel 1. Luas areal, Produksi, dan Produktivitas Kelapa Kota Tomohon

\begin{tabular}{|c|c|c|c|}
\hline Tahun & Luas (Ha) & Produksi (Ton) & Produktivitas $(\mathrm{Kg} / \mathrm{Ha})$ \\
\hline 2013 & $1.179,28$ & 379,73 & 322,00 \\
\hline 2014 & $1.177,98$ & 180,98 & 153,64 \\
\hline 2015 & $1.176,40$ & 351,61 & 298,88 \\
\hline
\end{tabular}

Produksi kelapa di Kota Tomohon tergantung dari hasil produksi kelapa pada beberapa daerah penghasil komoditas tersebut. Hampir semua Kecamatan di Kota Tomohon merupakan penghasil kelapa, termasuk Kecamatan Tomohon Barat. Melihat kegiatan industri Kopra terutama pada masyarakat yang berada di Kecamatan Tomohon Barat dalam memproduksi Kopra ada banyak masalah yang membuat produksi Kopra menurun, sehingga mengakibatkan pendapatan para petani sering tidak menentu. Hal ini disebabkan kurangnya pemahaman dari para petani tentang bagaimana cara mengolah Kopra dengan baik. Maka dari itu diperlukan analisis yang tepat untuk dapat menghasilkan produksi yang lebih baik dalam pengolahan Kopra bagi para petani Kopra. Dengan memanfaatkan faktor produksi asli seperti lahan, tenaga kerja, modal dan teknologi yang digunakan, maka para petani harus lebih memperhatikan penggunaan faktor produksi yang sesuai agar bisa menciptakan keseimbangan dengan hasil yang diperoleh.

\section{Kopra}

Kopra adalah daging buah kelapa yang dikeringkan. Kopra merupakan salah satu produk turunan kelapa yang sangat penting, karena merupakan bahan buku pembuatan minyak Kelapa dan turunannya. Untuk membuat Kopra yang baik diperlukan Kelapa yang telah berumur sekitar 300 hari dan memiliki berat sekitar 3-4 kg daging kelapa didapat dengan mencungkil dari tempurung secara manual atau memakai mesin cungkil Kopra kemudian dikeringkan dengan bantuan sinar matahari atau panas buatan. Kopra yang baik sebaiknya hanya memiliki kandungan air 6\%-7\% agar tidak mudah terserang organisme pengganggu. Kerusakan yang terjadi pada Kopra pada umumnya disebabkan oleh serangan bakteri dan serangan cendawan. Serangan tersebut mudah terjadi jika kadar air dalam Kopra tinggi, kelembaban udara mencapai $80 \%$ atau lebih dan suhu atsmosfer mencapai $30^{\circ} \mathrm{C}$. Cendawan yang sering menyerang Kopra adalah cendawan Rhizopus sp, Aspergillus niger, dan Penicillium glaucum.

\section{Konsep Produksi}

\section{Pengertian Produksi}

Produksi dalam arti ekonomi mempunyai pengertian semua kegiatan yang meningkatkan nilai kegunaan atau faedah (utility) suatu benda. Menurut teori produksi terdapat istilah faktor faktor produksi dan fungsi produksi. Faktor faktor produksi dalam teori produksi diartikan sebagai unsur - unsur yang dapat digunakan dalam proses produksi, sedangkan fungsi produksi adalah hubungan antara masukan produksi (input) dan hasil (output).

Menurut Sugiarto (2000), produksi

suatu kegiatan yang mebgubah input menjadi output. Pengertian produksi lainnya adalah hasil akhir dari proses atau aktivitas ekonomi dengan memanfaatkan beberapa masukan atau input. Pengertian ini dapat dipahami bahwa kegiatan produksi diartikan sebagai aktivitas dalam menghasilkan output dengan menggunakan teknik prooduksi tertentu untuk mengolah atau memproses input sedemikian rupa (Sukimo, 2002). 
Kegiatan produksi adalah usaha atau kegiatan manusia untuk menciptakan atau mempertinggi nilai guna ekonomi suatu barang atau jasa agar lebih berguna bagi pemenuhan kebutuhan manusia. Dalam bidang ekonomi, produksi mempunyai arti yang luas yaitu:

1. Mendapatkan barang yang disediakan alam, seperti hasil tambang, hasil hutan dan laut. Kegiatan tersebut termasuk kegiatan produksi bidang ekstraktif.

2. Mengerjakan atau mengolah tanah, seperti pertanian dan perkebunan, termasuk kegiatan produksi bidang agraris.

3. Mengolah bahan mentah menjadi bahan baku jadi, merupakan kegiatan produksi industry.

4. Mengumpulkan, menyalurkan, serta memasarkan hasil produksi kke tempat tempat yang membutuhkan, termasuk kegiatan produksi bidang perdagangan.

5. Menghasilkan atau menyediakan jasa asuransi, jasa transportasi, jasa perbankan, dan jasa perhotelan, termasuk kegiatan produksi dibidang jasa.

\section{Jenis - Jenis Faktor Produksi}

Jalannya suatu kegiatan produksi tergantung dari tersedianyaa faktor produksi. Faktor produksi adalah segala sesuuatu yang diperlukan dalam kegiatan produksi terhadap suatu barang dan jasa. Secara umum faktor faktor produksi dapat dibagi menjadi empat macam :

\section{Faktor produksi alam}

Faktor produksi alam atau sumber daya alam adalah semua kandungan alam yang dapat digunakan dalam proses produksi. Contoh : tanah, air, udara, tumbuh - tumbuhan, hewan dan lain sebagainya.

2. Faktor produksi tenaga kerja

Faktor produksi tenaga kerja merupakan pelaksana dalam kegiatan produksi.Pada umumnya faktor produksi tenaga kerja dapat dikelompokan berdasarkan sifat kerja dan kualitas hasil kerja. Faktor produksi alam dan tenaga kerja disebut faktor produksi asli. Macam -macam tenaga kerja :

a. Berdasarkan sifat kerja.

- Tenaga kerja jasmaniah : tenaga kerja yang mengandalkan kekuatan fisik (otot), seperti tukang becak, ukang batu, sopir dan penjaga malam.
- Tenaga kerja rohaniah : tenaga kerja yang didasarkan perusahaan atau pikiran : guru, peneliti, pengacara, penceramah dan lain lain.

b. Berdasarkan kualitas kerja

- Tenaga kerja terdidik : Tenaga yang memerlukan pendidikan sebelum berperan dalam kegiatan. Contoh, dokter, guru, dokter.

- Tenaga kerja terlatih : Tenaga kerja yang sebelummnya harus mengikuti latiihan terlebih dahulu sebelum mengikuti proses produksi. Contoh : sopir, penjahit, montir, dan lain sebagainya.

- Tenaga kerja kasar atau tenaga kerja terdidik dan ridak terlatih : Tenaga kerja tidak memerlukan pendidikan atau pelatihan terlebih dahulu, seperti kuli bangunan, pesuruh, tukang parker, tukang sapu dan lain sebagainya.

3. Faktor produksi modal

Pengertian dari produksi modal adalah semua hasil produksi manusia yang akan digunakan utuk menghasilkan barang dan jasa. Contoh : uang, mesin,, alat pertanian, alat transportasi dan lainnya sebagainya. Barang barang modal disebut juga dengan alat - alat produksi. Modal akan dikelompokkan berdasarkan waktu penggunaan pemilik (subyek),

a. Berdasarkan waktu penggunaannya modal dapat dibagi menjadi dua macam yaitu :

- Modal tetap : Modal yang tetap dann dapat digunakan beberapa kali ,dalam proses produksi. Contoh : /gedung, pabrik, mesin mesin, traktor, dan lain sebagainya.

- Modal lancer : modal lancer dapat digunakan hanya dalam satu kali proses produksi. Contoh: bahan baku, bahan penolong, bahan bakar, dan lain sebagainya.

b. Berdasarkan pemiliknya

Berdasarkan pemiliknya modal dapat dibagi menjadi dua juga, yaitu sebagai berikut :

- Modal individu : modal individu dimiliki oleh perseorangan dan akan memberikan hasil pada yang memilikinya. Contoh : bunga, tabungan, sewa rumah, dan dapat kos.

- Modal kelompok (sosial) : Modal kelompok dimiliki secara bersama oleh masyarakat dan memberikan manfaat bagi orang banyak. Contoh : rumah sakit, puskesmas, jalan raya, dan lain sebagainya. 
c. Berdasarkan Bentuknya

Berdasarkan bentuknya, modal dapat dibedakkan menjadi dua, yaitu :

- Modal Nyata : Modal nyata dapat berupa barang yang dapat digunakan dalam proses produksi.

- Modal Abstrak : Modal yang tidak dapat dilihat dan diraba namun mempunyai nilai dalam produksi dan hasilnya dapat dirasakan. Contoh: kepandaian, pengetahuan, keahlian dan lain sebagainya.

d. Berdasarkan Sumbernya

Berdasarkan sumbernya, modal dapat dibedakan menjadi dua, yaitu sebagai berikut :

- Modal Sendiri : Yaitu modal yang bersumber dari pemiliknya sendiri atau dari penyisihan keuntungan yang diperoleh.

- Modal Pinjaman : Yaitu modal yang bersumber dari pinjaman dari pihak lain, yaitu berupa hutang.

4. Faktor Produksi Kewirausahaan

Kewirausahaan adalah kemampuan seorang untuk dapat mengkombinasikan faktor - faktor produksi alam, tenaga kerja, dan modal untuk menghasilkan barang atau jasa dalam usahanya memperoleh keuntungan.

Kemampuan yang harus dimiliki seorang pengusaha, antara lain :

a. Perencanaan (planning) : Kemampuan ini mencakup penetapan tujuan dan penentuan strategi.

b. Pengorganisasian (Organizing) : Kemampuan ini mencakup pembagian tugas dan wewenang, mengatur hubungan dan tanggung jawab.

c. Pengarahan (Directing) : Kemampuan ini mencakup dorongan dan bimbingan serta pengawasan terhadap pelaksanaan pekerjaan.

d. Pengawasan (Controling) : Kemampuaan ini mencakup pengukuran dan penilaian hasil pekerjaan agar sesuai dengan perencanaan.

\section{Fungsi Produksi}

Assauri (1993) memberikan definisi fungsi produksi adalah sebagai pertanggung jawaban dalam pengolohan dan transformasian masukan (input) menjadi keluaran (output) berupa barang dan jasa yang dapat memberikan hasil pendapatan bagi perusahaan. Untuk melaksanakan fungsi tersebut diperlukan serangkaian kegiatan yang merupakan keterkaitan dan menyatu serta menyeluruh sebagai suatu sistem. Berbagai kegiatan yang berkaitan dengan fungsi produksi dan operasi ini dilaksanakan oleh beberapa bagian yang terdapat dalam suatu

Perusahaan itu berupa perusahaan besar, maupun perusahaan itu adalah perusahaan kecil. Empat fungsi produksi dan operasi adalah :

1. Proses pengolahan, merupakan metode atau teknik yang digunakan untuk pengolahan masukan (input).

2. Jasa - jasa penunjang, merupakan sarana yang berupa pengorganisasian yang perlu untuk penetapan teknik dan metode yang digunakan atau dijalankan, sehingga proses pengolahan dapat dilaksanakan secara efektif dan efisien.

3. Perencanaan, merupakan proses penetapan keterkaitan dan pengorganisasian dari kegiatan produksi dan operasi yang akan dilakukan dalam dasar waktu atau periode waktu.

4. Pengendalian atau perawatan, merupakan fungsi untuk menjamin terlaksananya kegiatan sesuai dengan yang direncanakan, sehingga maksud dan tujuan untuk penggunaan dan pengolahan masukan (input) pada kenyataannya dilaksanakan.

Fungsi Produksi (Sri Adiningsih, 2003)

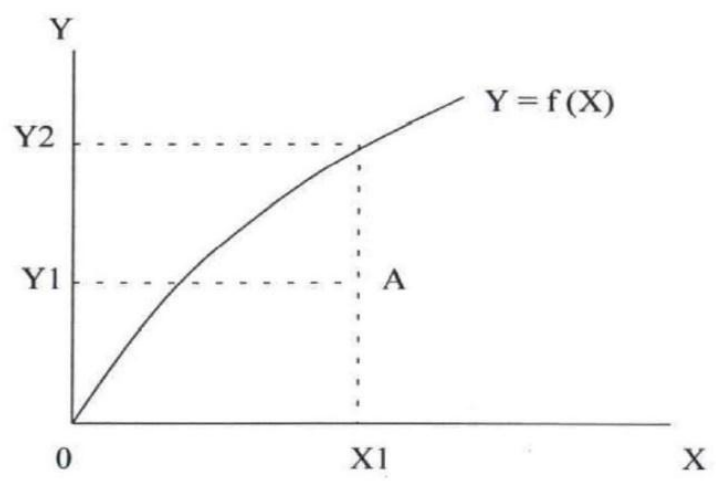

Everet dan Ebert (1992) memberikan definisi atau pengertian fungsi produksi merupakan kegiatan untuk menciptakan atau menambah kegunaan suau barang, mengubah sesuatu yang nilainya lebih rendah menjadi sesuatu yang memiliki nilai lebih tinggi dengan menggunakan sumber daya yang ada, seperti bahan baku, tenaga kerja, mesin dan sumber - sumber lainnya, shingga produk yang dihasilkan dapat memberikan kepuasan pada konsumen. 
Fungsi produksi adalah suatu fungsi yang menunjukkan hubungan matematik antara input yang digunakan untuk menghasilkan suatu tingkat output tertentu (Nicholson, 2002). Fungsi produksi merupakan suatu fungsi atau persamaan yang menunjukkan sifat perkaiitan antara faktor factor produksi dengan tingkat produksi yang diciptakan. Faktor produksi juga dikenal dengan istilah input dan output.

Rumus fungsi produksi : $\mathrm{Q}=\mathrm{f}(\mathrm{L}, \mathrm{C}, \mathrm{R}, \mathrm{S})$ dimana :

$$
\begin{aligned}
& \mathrm{Q}=\text { tingkat produksi yang dihasilkan (output) } \\
& \mathrm{L}=\text { tenaga kerja } \\
& \mathrm{C}=\text { jumlah modal } \\
& \mathrm{R}=\text { kekayaan alam } \\
& \mathrm{S}=\text { kewirausahaan }
\end{aligned}
$$

\section{Elastisitas Produksi}

Elastisitas adalah konsep kuantitatif yang sangat penting untuk mengidentifikasi secara kuantitatif respon sebuah variabel karena perubahan variabel lain. Elastisitas produksi (Ep) sendiri menunjukkan presentase perubahan output sebagai akibat dari perubahan input (sudarsugiart dalam Joesran dan Fathorozi, 2003).

Secara matematis dapat diformulasikan sebagai berikut :

$$
E p=\frac{d Y / Y}{d X / X} \text { atau sama dengan } \frac{d Y}{d X} \times \frac{X}{Y}
$$

Analisis elastisitas input ini sangat penting untuk menjelaskan input mana yang lebih elastis dibanding dengan input lainnya. Disamping itu, sekaligus dapat diketahui intensitas faktor produksinya, apakah bersifat padat tenaga kerja atau padat modal. Apabila nilai $\beta 1>\beta 2$ maka proses produksi lebih bersifat padat capital dan sebaliknya.

\section{Uji Asumsi Klasik}

Menurut Kuncoro (2013), model regresi yang valid harus memenuhi kriteria BLUE (Best, Linear, Unbiased, and Estimated). Untuk dapat mengetahui apakah model regresi dalam suatu penelitian telah memenuhi kriteria BLUE, maka perlu dilakukan uji prasyarat regresi linier berganda, yaitu uji Asumsi Klasik. Beberapa pengujian Asumsi Klasik yang sering dilakukan pada model regresi linier berganda, yaitu antara lain Normalitas, Multikolinieritas, Autokorelasi, dan Heteroskedastisitas.

\section{Uji Normalitas Data}

Adisetiawan (2011) mengungkapkan tujuan uji normalitas adalah untuk menguji apakah variabel dependen dan independen berdistribusi normal atau tidak, dan salah satu cara untuk mengetahuinya adalah dengan normal probability plots.

Menurut Ghozali (2005), pengujian normal probability plots dilakukan dengan cara melihat titik-titik penyebaran data terhadap garis diagonal pada grafik. Kriteria pengambilan keputusan uji normal probability plots adalah sebagai berikut :

- Apabila data (titik-titik pada grafik) menyebar dan mengikuti garis diagonal, maka disimpulkan bahwa data mengikuti pola distribusi normal.

- Apabila data (titik-titik pada grafik) menyebar dan cenderung menjauh dari garis diagonal serta tidak mengikuti garis diagonal, maka dapat disimpulkan bahwa data tidak menunjukkan pola distribusi normal.

\section{Uji Multikolinieritas}

Untuk memenuhi kriteria BLUE, tidak boleh terdapat korelasi antara variabel independent pada model regresi. Menurut Ghozali (2005), uji multikolinieritas bertujuan untuk mendeteksi apakah variabel independent pada model regresi saling berkorelasi. Salah satu cara untuk mendeteksi gejala multikolinieritas adalah dengan melihat nilai tolerance value atau Variance Inflation Factor (VIF) dengan kriteria keputusan sebagai berikut:

- Apabila tolerance value $>0.1$ dan VIF $<10$, maka dapat disimpulkan tidak terjadi gejala multikolinieritas antar variabel independent pada model regresi.

- Apabila tolerance value < 0.1 dan VIF > 10, maka dapat disimpulkan terjadi gejala multikolinieritas antar variabel independent pada model regresi.

\section{Uji Autokorelasi}

Uji autokorelasi digunakan untuk mendeteksi apakah terjadi korelasi antara residu pada periode saat ini ( $t$ ) dengan residu pada periode sebelumnya ( $\mathrm{t}-1)$. Untuk memenuhi kriteria BLUE. Model regresi harus terbebas dari gejala autokorelasi. Masalah autokorelasi cenderung terjadi pada penelitian dengan menggunakan data time series, dibandingkan data cross section. 
Alfigari (2000) mengungkapkan bahwa untuk mendeteksi gejala autokorelasi dapat menggunakan uji statistik yaitu uji Durbin-Watson dengan kriteria pengambilan keputusan sebagai berikut :

- Apabila dw < dl, maka terjadi autokorelasi negatif

- Apabila dl $<\mathrm{dw}<\mathrm{du}$, maka tidak dapat disimpulkan

- Apabila du $<\mathrm{dw}<4-\mathrm{du}$, maka tidak terjadi autokorelasi negatif dan positif

- $\quad$ Apabila $4-\mathrm{du}>\mathrm{dw}<4-\mathrm{dl}$, maka tidak dapat disimpulkan

- Apabila 4 - dl< dw, maka terjadi autokorelasi positif

\section{Uji Heteroskedastisitas}

Uji Heteroskedastisitas dilakukan untuk mengetahui apakah dalam model regresi terjadi ketidaksamaan variance dari residual satu pengamatan ke pengamatan lain. Model regresi yang baik harus memiliki variance yang sama (homoskedastisitas). Gejala heteroskedastisitas sering terjadi pada penelitian yang menggunakan data cross section dan sangat jarang terjadi pada penelitian yang menggunakan data time series.

\section{Rumusan Masalah}

Berdasarkan uraian diatas maka menjadi rumusan masalah dalam penelitian ini, adalah : produksi yang digunakan terhadap produksi Kopra di Kecamatan Tomohon Barat?

2. Bagaimana besaran elastisitas dari faktorfaktor produksi Kopra di Kecamatan Tomohon Barat?

\section{Tujuan Penelitian}

1. Untuk mengidentifikasi faktor - faktor produksi yang mempengaruhi produksi Kopra dari para petani penghasil Kopra yang berada di Kecamatan Tomohon Barat.

2. Untuk menganalisa elastisitas faktor produksi Kopra di Kecamatan Tomohon Barat.

\section{Manfaat Penelitian}

Kegunaan penelitian ini bermanfaat untuk :

1. Bagi Penulis :

a. Untuk memenuhi salah satuu syarat untuk menyelesaikan studi pada Universitas Sam Ratulangi Fakultas Pertanian Jurusan Sosial Ekonomi Program Studi Agribisnis.

b. Menerapkan ilmu - ilmu yang dipelajari selama perkuliahan dalam hal ini meningkatkan pengetahuan mengenai teori produksi.

2. Bagi para petani yang memproduksi Kopra, diharapkan dengan adanya penelitian ini dapat menjadi bahan pertimbangan bagi para petani dalam hal pengambilan keputusan yang berhubungan dengan keseimbangan faktor produksi yang digunakan dalam mencapai produktivitas Kopra yang sesuai.

3. Bagi yang membaca, dapat menjadi sumber informasi dan masukan yang dapat digunakan dalam penelitian selanjutnya.

\section{METODOLOGI PENELITIAN}

\section{Lokasi Dan Waktu Penelitian}

Penelitian ini berlangsung selama 4 (empat) bulan yaitu bulan Januari sampai April 2017, sejak dari tahap persiapan sampai pada penyusunan laporan hasil. Lokasi penelitian dilaksanakan di Kecamatan Tomohon Barat.

\section{Metode Penentuan Sampel}

Populasi dalam penelitian ini adalah petani Kopra yang terdapat di Kecamatan Tomohon Barat. Menurut data BP3K Tomohon Barat pada tahun 2017, jumlah seluruh petani Kopra di Kecamatan Tomohon Barat yaitu \pm 800 petani.

Penentuan sampel kelurahan dilakukan secara purposive sampling (sengaja) berdasarkan pertimbangan kelurahan tersebut merupakan sentra produksi kelapa di Kecamatan Tomohon Barat, yaitu antara lain Kelurahan Taratara, Taratara I, Woloan III, dan Woloan I. Sampel petani ditetapkan dengan menggunakan metode simple random sampling (acak sederhana). Penentuan jumlah sampel petani menggunakan formula Slovin (Sri Marmi, 2008):

$$
\mathrm{n}=\mathrm{N} / \mathrm{N}(\mathrm{d})^{2}+1
$$


Keterangan :

$$
\mathrm{n}=\text { sampel; }
$$

$\mathrm{N}=$ populasi;

$\mathrm{d}=$ nilai presisi $90 \%$ atau sig. $=0,1$

Diketahui jumlah populasi petani Kopra

di Kecamatan Tomohon Barat yaitu \pm 800 petani, sehingga berdasarkan formula Slovin diperoleh jumlah petani sampel yaitu \pm 90 petani.

$$
\begin{aligned}
\mathrm{n} & =800 / 800(0,1) 2+1 \\
& =88,88 \\
& \approx 89
\end{aligned}
$$

\section{Metode Pengumpulan Data}

Data yang dikumpulkan dalam penelitian ini meliputi data primer dan sekunder. Data primer diperoleh dengan menggunakan metode survey melalui pengamatan dan wawancara langsung dengan para petani penghasil Kopra dalam bentuk kuesioner.

Data sekunder adalah data yang telah tersusun dalam bentuk dokumen tertulis seperti buku, arsip, literatur dan laporan yang diperoleh dari instansi pemerintah baik tingkat desa dan Kecamatan, serta yang diperoleh melalui media internet.

\section{Metode Analisis Data \\ 1. Penentuan Model Fungsi Produksi}

Analisis data untuk mengetahui pengaruh faktor produksi Kopra di Kecamatan Tomohon Barat ini menggunakan fungsi produksi CobbDouglas, dengan bentuk sebagai berikut:

$$
\mathrm{Y}=\alpha X_{1}^{\beta 1} \alpha X_{2}^{\beta 2} \alpha X_{3}^{\beta 3} \alpha X_{4}^{\beta 4} \alpha X_{5}^{\beta 5}
$$

Selanjutnya agar fungsi produksi diatas dapat ditaksir maka persamaan tersebut perlu ditransformasikan kedalam bentuk linier menjadi :

\section{Keterangan:}

$$
\ln Y=\ln \alpha_{1}+\beta_{1} \ln X_{1}+\beta_{2} \ln X_{2}+\beta_{3} \ln X_{3}+\beta_{4} \ln X_{4}+\varepsilon
$$

$\mathrm{Y}=$ Produksi Kopra (ton)

$\mathrm{X} 1=$ Luas tanam $(\mathrm{Ha})$

$\mathrm{X} 2=$ Populasi tanaman kelapa (pohon)

$\mathrm{X}_{3}=$ Penggunaan tenaga kerja $(\mathrm{HOK})$

$\mathrm{X}_{4}=$ Peralatan (unit)

$\mathrm{X}_{5}=$ Pengalaman (tahun)

$\alpha=$ intersep

$\beta 1, \beta 2, \beta 3, \beta 4=$ Elastisitas faktor produksi

$\varepsilon=$ Error

\section{Pengujian Model}

a. Uji Asumsi Klasik

Uji Asumsi Klasik merupakan keharusan bagi penelitian model regresi linier berganda, untuk memenuhi kriteria BLUE (Best, Linear, Unbiased, and Estimated). Uji asumsi klasik yang dilakukan pada penelitian ini meliputi Uji Normalitas, Uji Multikolinieritas, dan Uji Heteroskedastisitas.

b. Uji Statistik

- Koefisien Determinasi $\left(\mathrm{R}^{2}\right)$

$$
\text { Koefisien determinasi }
$$

mengindikasikan seberapa baik keseluruhan model regresi dalam menerangkan perubahan dalam nilai variabel terikat (Gujarati, 1997). Secara matematis ditulis :

$$
\mathrm{R}^{2}=\frac{S S R}{S S T}
$$

Keterangan :

$\mathrm{SSR}=$ Jumlah regresi kuadrat (Sum of Square for Regression)

SST $=$ Jumlah kuadrat total (Sum of Square Total)

Koefisien determinasi yang rendah menunjukkan bahwa model tersebut tidak memadai untuk menjelaskan hal yang diteliti

- Uji Statistik F

Uji statistik $F$ ditujukan untuk mengetahui bagaimana pengaruh variabel bebas yang dimasukkan dalam model mempunyai pengaruh terhadap variabel terikat secara bersama-sama (simultan). Secara matematis ditulis (Widarjono, 2007) :

$$
\mathrm{F}_{\mathrm{k}-1, \mathrm{n}-\mathrm{k}}=\frac{E S S /(n-k)}{R S S /(n-k)}=\frac{R^{2} /(k-1)}{\left(1-R^{2}\right) /(n-k)}
$$

Keterangan :

$\mathrm{n}=$ Jumlah Sampel

$\mathrm{K}=$ Jumlah parameter

$\mathrm{ESS}=$ ErrorSum of Square

$\mathrm{SST}=$ ResidualSum of Square Total

$\mathrm{R}^{2}=$ Koefisien determinasi

Hipotesis penelitian yang akan dibuktikan adalah : $\mathrm{H} 0: \beta 1=\beta 2=\beta 3=\beta 4=0$ (luas tanam, populasi tanaman, tenaga kerja, peralatan, dan pengalaman secara bersama-sama (simultan) bukan merupakan penjelas yang signifikan terhadap produksi Kopra) 
H1 : $\beta 1 \neq \beta 2 \neq \beta 3 \neq \beta 4 \neq=0$ (luas tanam, populasi tanaman, tenaga kerja, peralatan, dan pengalaman secara bersama-sama (simultan) merupakan penjelas yang signifikan terhadap produksi Kopra)

\section{Kriteria Uji :}

- Jika nilai Fhitung > Ftabel atau nilai signifikannya lebih kecil daripada tingkat kesalahan yang ditetapkan $(<)$, maka hipotesis nol $\mathrm{H} 0$ ditolak dan $\mathrm{H} 1$ diterima, berarti variabel bebas(luas tanam, populasi tanaman, tenaga kerja, peralatan, dan pengalaman) secara keseluruhan berpengaruh terhadap variabel terikat (produksi Kopra).

- Jika nilai Fhitung < Ftabel atau nilai signifikannya lebih besar daripada tingkat kesalahan yang ditetapkan (> ), maka hipotesis nol H0 diterima dan H1 ditolak, berarti variabel bebas (luas tanam, populasi tanaman, tenaga kerja, peralatan, dan pengalaman) secara keseluruhan tidak berpengaruh terhadap variabel terikat (produksi Kopra).

\section{c. Uji Statistik T}

Uji statistik $\mathrm{T}$ digunakan untuk mengetahui pengaruh masing - masing variabel bebas terhadap variabel terikat. Uji $\mathrm{T}$ merupakan rasio antar nilai dari parameter estimasi dengan standar deviasinya. Secara matematis ditulis (Widarjono, 2007) :

$$
\mathrm{T}=\frac{\beta i}{S_{\beta i}}
$$

Keterangan : $\beta \mathrm{i}=$ Parameter yang diestimasi

$$
\mathrm{S}_{\beta \mathrm{i}}=\text { Standar error } \text { parameter }
$$

Hipotesis penelitian yang akan dibuktikan adalah :

- $\mathrm{H} 0$ : $\mathrm{B} 1=\mathrm{O}$; artinya secara individual variabel bebas tidak berpengaruh secara signifikan terhadap variabel terikat.

- $\mathrm{H} 1: \beta 1 \neq \mathrm{O}$; artinya secara individual variabel bebas berpengaruh secara signifikan terhadap variabel terikat.

Kriteria Uji :

- Jika nilai Thitung >Ttabel, maka hipotesis nol $\mathrm{H} 0$ ditolak dan $\mathrm{H} 1$ diterima, berarti signifikansi atau variabel bebas (luas tanam, populasi tanaman, tenaga kerja, peralatan, dan pengalaman) yang diuji secara individual, berpengaruh nyata terhadap variabel terikat (produksi Kopra).

Jika nilai Fhitung < Ftabel, maka hipotesis nol $\mathrm{H} 0$ ditolak dan $\mathrm{H} 1$ diterima, berarti signifikansi atau variabel bebas (luas tanam, populasi tanaman, tenaga kerja, peralatan, dan pengalaman) yang diuji secara individual, tidak berpengaruh nyata terhadap variabel terikat (produksi Kopra).

\section{Konsep Pengukuran Variabel}

Variabel-variabel yang diukur dalam penelitian ini adalah :

1. Karakteristik petani sampel (penghasil Kopra) meliputi :

a. Umur, dilihat dari umur kepala keluarga yang mengelola usahatani Kelapa (tahun)

b. Tingkat pendidikan, dilihat dari tingkat pendidikan kepala keluarga yang mengelola usahatani kelapa dibagi atas :

- Tamat SD

- Tamat SMP

- Tamat SMA dan Perguruan Tinggi

c. Jumlah anggota keluarga, yaitu jumlah tanggungan petani Kelapa (orang)

d. Status pengusahaan usahatani kelapa (milik sendiri / sewa / pinjam / hasil bagi)

e. Lama pengusahaan usahatani kelapa (tahun)

2. Luas tanam, yaitu luas lahan yang digarap oleh petani untuk menghasilkan Kopra dan diukur dalam satuan hektar.

3. Populasi Tanaman Kelapa, yaitu banyaknya pohon Kelapa yang ditanam dalam satu hektar, dinyatakan dalam satuan pohon.

4. Produksi Kopra, yaitu jumlah Kopra yang dihasilkan oleh setiap petani dan dinyatakan dalam satuan kilogram. 
5. Curahan Tenaga kerja, yaitu banyaknya orang atau tenaga kerja yang digunakan untuk memproduksi Kopra dan dinyatakan dalam satuan Hari Orang Kerja (HOK).

6. Modal (peralatan), yaitu jumlah peralatan yang digunakan dalam memproduksi Kopra, dinyatakan dalam satuan unit.

\section{HASIL DAN PEMBAHASAN}

\section{Karakteristik Sampel Petani Penghasil Kopra}

\section{Umur}

Hasil penelitian menunjukan bahwa ratarata petani penghasil Kopra di Kecamatan Tomohon Barat berusia 56,82 tahun Berikut data golongan umur sampel petani penghasil Kopra di Kecamatan Tomohon Barat dapat dilihat pada Tabel 2.

Tabel 2. Golongan Umur Petani Penghasil Kopra di Kecamatan Tomohon Barat

\begin{tabular}{|c|c|c|}
\hline \multirow[t]{2}{*}{$\begin{array}{l}\begin{array}{c}\text { GolonganUmur } \\
\text { petani (tahun) }\end{array} \\
\end{array}$} & \multicolumn{2}{|c|}{ Petani } \\
\hline & Jumlah (Orang) & Persentase $(\%)$ \\
\hline$\leq 45$ & 3 & 3,37 \\
\hline $46-59$ & 53 & 59,55 \\
\hline$\geq 60$ & 33 & 37,08 \\
\hline Total & 89 & 100,00 \\
\hline
\end{tabular}

Tabel 2 menunjukkan bahwa kisaran umur sampel petani penghasil Kopra yaitu 42 - 67 tahun, dan sebagian besar berada pada kelompok umur 46 - 59 tahun, dengan jumlah petani sebanyak 53 orang atau 59,55\%. Diikuti pada kelompok umur $\geq 60$ dan $\leq 45$ tahun yaitu masing-masing sebanyak 33 orang atau sebesar $37,08 \%$ dan 27 orang atau sebesar $3,37 \%$.

\section{Tingkat Pendidikan}

Data tingkat pendidikan sampel petani penghasil Kopra di Kecamatan Tomohon Barat terangkum pada Tabel 3.

Tabel 3. Tingkat Pendidikan Petani Penghasil Kopra di Kecamatan Tomohon Barat

\begin{tabular}{lcc}
\multicolumn{1}{c}{ Kingkat Pendidikan } & Petani \\
& $\begin{array}{c}\text { Jumlah } \\
\text { (Orang) }\end{array}$ & Persentase (\%) \\
\hline Sekolah Dasar (SD) & 15 & 16,85 \\
Sekolah Menengah & 58 & 65,17 \\
Pertama (SMP) & 16 & 17,98 \\
Sekolah Menengah Atas & & \\
(SMA/STM)) & & 100,00 \\
\hline Total & 89 & \\
\hline Sumber: Diolah dari data primer, 2018
\end{tabular}

Pada Tabel 3 didapati bahwa sebagian besar petani penghasil Kopra di Kecamatan Tomohon Barat berpendidikan sedang. Hal ini terlihat pada nilai persentase terbesar yakni sebanyak 58 orangatau $65,17 \%$ berpendidikan SMP. Selebihnya sebanyak 15 orang atau $16,85 \%$ berpendidikan SD dan sebanyak 16 orang atau sebesar 17,98 \% berpendidikan SMA.

\section{Status Kepemilikan}

Sebagian besar petani penghasil Kopra di Kecamatan Tomohon Barat mengelola sendiri usahataninya, atau berstatus sebagai pemilik / milik sendiri, namun ada beberapa yang mengelola usahatani bukan milik sendiri atau sewa. Status kepemilikan sampel petani penghasil Kopra dapat dilihat pada Tabel 4.

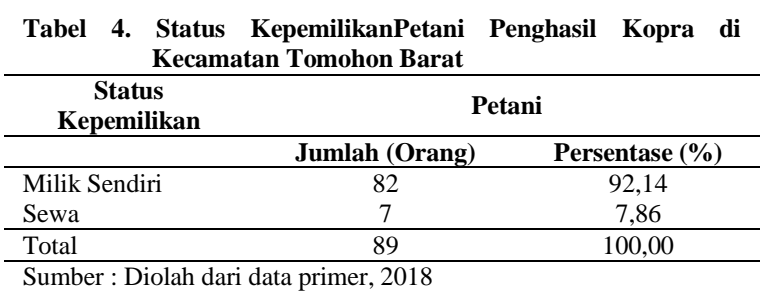

Pada Tabel 4 dapat dilihat bahwa sebagian besar petani yakni sebanyak 82 orang atau sebesar $92,14 \%$ mengusahakan sendiri usahataninya, sedangkan sisanya yaitu sebanyak 7 petani atau $7,86 \%$ mengusahakan usahatani dengan cara sewa.

\section{Lama Berusahatani}

Rata-rata lamanya pengusahaan usahatani kelapa di Kecamatan Tomohon Barat yaitu 23 tahun, dengan minimum lama berusahatani 8 tahun dan maksimum 45 tahun. Lamanya pengusahaan usahatani akan membentuk petani menjadi lebih berpengalaman dan memiliki banyak pengetahuan terutama tentang usahatani yang dikelolanya.

Berikut data lama berusahatani sampel petani penghasil Kopra di Kecamatan Tomohon Barat yang terangkum pada Tabel 5.

\begin{tabular}{|c|c|c|}
\hline \multirow[t]{2}{*}{ Lama Berusahatani } & \multicolumn{2}{|c|}{ Petani } \\
\hline & Jumlah (Orang) & Persentase (\%) \\
\hline$\leq 15$ & 21 & 23,59 \\
\hline $16-29$ & 49 & 55,06 \\
\hline$\geq 30$ & 19 & 21,35 \\
\hline Total & 89 & 100,00 \\
\hline
\end{tabular}


Pada Tabel 5 menunjukkan sebagian besar petani penghasil Kopra telah berusahatani selama $16-29$ tahun yaitu sebanyak 49 orang atau $55,06 \%$. Selanjutnya sebanyak 21 orang atau 23,59\%telah berusahatani dibawah 15 tahun, sedangkan selebihnya yaitu sebanyak 19 orang atau sebesar $21,35 \%$ berusahatani selama diatas 30 tahun.

\section{Luas Tanam dan Jumlah Populasi Tanaman Kelapa}

\section{Luas Tanam}

Hasil penelitian menunjukkan bahwa rata-rata luas tanam pada usahatani Kelapa di Kecamatan Tomohon Barat yaitu 2,17 hektar, dengan luas tanam minimum yang dikuasai petani 0.5 hektar dan maksimum 6 hektar. Data luas tanam usahatani kelapa di Kecamatan Tomohon Barat dapat dilihat pada Tabel 6 berikut ini.

Tabel 6. Data Luas Tanam Usahatani Kelapa di Kecamatan Tomohon Barat

\begin{tabular}{lcc}
\hline Luas Tanam & \multicolumn{2}{c}{ Petani } \\
\hline \multicolumn{1}{c}{ Jumlah (Orang) } & Persentase (\%) \\
$1,6-2,9$ & 32 & 35,96 \\
$\geq 3$ & 33 & 37,08 \\
& 24 & 26,96 \\
\hline Total & 89 & 100,00 \\
\hline \multicolumn{2}{l}{ Sumber : Diolah dari data primer, 2018}
\end{tabular}

Pada Tabel 6 diketahui bahwa sebagian besar petani penghasil Kopra di Kecamatan Tomohon Barat menguasai lahan dengan luas tanam 1,6 - 2,9 hektar yaitu sebanyak 33 orang atau 37,08\%. Diikuti oleh petani penghasil Kopra dengan luas tanam $\leq$ 1,5 hektar yaitu sebanyak 32 orang atau sebesar $35,96 \%$. Selebihnya sebanyak 24 orang atau $26,96 \%$ menguasai luas tanam sebesar $\geq 3$ hektar.

\section{Jumlah Populasi Tanaman Kelapa}

Populasi tanaman kelapa berpengaruh terhadap produksi Kopra, semakin banyak jumlah populasi tanaman semakin besar produksi, demikian pula sebaliknya. Hasil penelitian menunjukkan bahwa rata-rata populasi tanaman kelapa yang diusahakan oleh petani di Kecamatan Tomohon Barat yaitu 446,52 pohon, dengan jumlah populasi tanaman minimum yang diusahakan yakni 60 pohon dan maksimum 1.500 pohon.

Berikut data populasi tanaman kelapa yang diusahakan petani penghasil Kopra di Kecamatan Tomohon Barat terangkum pada Tabel 7.

Tabel 7. Populasi Tanaman Kelapa di Kecamatan Tomohon Barat

\begin{tabular}{ccc}
\hline Populasi Tanaman & \multicolumn{2}{c}{ Petani } \\
\hline & $\begin{array}{r}\text { Jumlah } \\
\text { (Orang) }\end{array}$ & Persentase (\%) \\
\hline$<300$ & 27 & 30,34 \\
$300-1000$ & 59 & 66,29 \\
$>1000$ & 3 & 3,37 \\
\hline Total & 89 & 100,00 \\
\hline
\end{tabular}

Sumber : Diolah dari data primer, 2018

Tabel 7 menunjukkan sebagian besar jumlah populasi tanaman yang diusahakan petani untuk menghasilkan Kopra yaitu antara $300-1000$ pohon yakni sebanyak 59 orang atau $66,29 \%$. Diikuti sebanyak 27 orang atau $30,34 \%$ mengusahakan populasi tanaman kurang dari 300 pohon, dan hanya 3 orang atau $3,37 \%$ yang mengusahakan populasi tanaman lebih dari 1000 pohon.

\section{Produksi Kopra dan Harga Jual}

Produksi merupakan suatu hasil dari kegiatan mengkombinasikan faktor-faktor produksi modal, tenaga kerja, teknologi dan managerial skill untuk meningkatkan manfaat. Besar kecilnya pendapatan petani sangat bergantung pada volume produksi. Semakin besar volume produksi yang dihasilkan maka semakin tinggi pula penerimaan yang akan diterima.

Produksi Kopra di Kecamatan Tomohon Baratrata-rata yaitu $1.720,22 \mathrm{~kg}$ per petani dan $1.844,94 \mathrm{~kg}$ per hektar. Produksi minimum Kopra per petani yakni $300 \mathrm{~kg}$ dan maksimum $6.000 \mathrm{~kg}$, sedangkan per hektar minimum sejumlah $600 \mathrm{~kg}$ dan maksimum sejumlah 2.000 kg.Harga jual yang berlaku pada saat penelitian dilakukan yaitu $\mathrm{Rp} 10.000$ per kg. Data produksi Kopra di Kecamatan Minahasa Barat dapat dilihat pada Tabel 8. 
Pada Tabel 8 diketahui bahwa sebagian besar petani Kopra di Kecamatan Tomohon Barat yakni 42 orang atau 47,19 \% memproduksi Kopra sebanyak $1.500-2.900$ Kopra. Diikuti sebanyak 31 orang atau 34,83\% memproduksi Kopra kurang dari 1.500 kg, sedangkan sisanya yakni sebanyak 16 orang atau $17,98 \%$ memproduksi Kopra sebanyak $3.000 \mathrm{~kg}$ keatas.

Tabel 8. Produksi Kopra di Kecamatan Tomohon Barat

\begin{tabular}{lcc}
\hline $\begin{array}{c}\text { Produksi } \\
\text { Kopra }\end{array}$ & \multicolumn{2}{c}{ Petani } \\
\hline & Jumlah (Orang) & Persentase (\%) \\
\hline$<1500$ & 31 & 34,83 \\
$1500-2900$ & 42 & 47,19 \\
$\geq 3000$ & 16 & 17,98 \\
\hline Total & 89 & 100,00 \\
\hline
\end{tabular}

Sumber : Diolah dari data primer, 2018

\section{Tenaga Kerja}

Tenaga kerja merupakan salah satu faktor produksi yang penting dalam berusahatani. Penggunaan tenaga kerja menggunakan satuan Hari Orang Kerja (HOK). Tenaga kerja yang digunakan oleh petani penghasil Kopra di Kecamatan Tomohon Barat meliputi kegiatan panen (panjat, pengupasan, pengangkutan) dan kegiatan pengolahan Kopra. Penggunaan tenaga kerja untuk masing-masing kegiatan tersebut disajikan pada Tabel 9.

\begin{tabular}{lc} 
Tabel 9. & $\begin{array}{l}\text { Rata-Rata Penggunaan Tenaga } \\
\text { Kerja pada Petani Penghasil Kopra } \\
\text { di Kecamatan Tomohon Barat }\end{array}$ \\
\hline Kegiatan Pengolahan Kopra & $\begin{array}{c}\text { Rata-rata Tenaga } \\
\text { Kerja (HOK) }\end{array}$ \\
\hline - Panen (panjat, pengupasan, & 17,42 \\
dan pengangkutan) & 49,06 \\
\hline - Pengolahan Kopra & 66,48 \\
\hline \multicolumn{2}{l}{ Total }
\end{tabular}

Pada Tabel 9 diperoleh, penggunaan ratarata tenaga kerja yang oleh petani penghasil Kopra di Kecamatan Tomohon Barat yaitu 66,48 HOK. Pada kegiatan panen (panjat, pengupasan, dan pengangkutan) rata-rata tenaga kerja yang digunakan yaitu $17,42 \mathrm{HOK}$, dan pada kegiatan pengolahan Kopra yaitu 49,06 HOK.
Penentuan HOK pada kegiatan pengolahan Kopra mudah diperoleh yaitu berdasarkan jumlah tenaga kerja dan jangka waktu yang ditempuh untuk mengolah kelapa menjadi Kopra. Bertolak belakang dengan uraian tersebut, penentuan HOK pada kegiatan panen berbeda. Biaya tenaga kerja pada kegiatan panen tidak mengacu pada $\mathrm{HOK}$ melainkan mengacu banyaknya pohon yang dipanenyakni Rp 5000 perpohon. Rata-rata biaya tenaga kerja yang dikeluarkan oleh petani penghasil Kopra di Kecamatan Tomohon Barat disajikan pada Tabel 10.

Tabel 10. Rata-Rata Biaya Tenaga Kerja pada Petani Penghasil Kopra di Kecamatan Tomohon Barat

\begin{tabular}{lc}
\hline \multicolumn{1}{c}{$\begin{array}{c}\text { Kegiatan Pengolahan } \\
\text { Kopra }\end{array}$} & $\begin{array}{c}\text { Rata-rata Biaya } \\
\text { Tenaga Kerja (Rp) }\end{array}$ \\
\hline - Panen (panjat, pengupasan, & $2.177 .808,89$ \\
dan pengangkutan) & $6.132 .584,27$ \\
- Pengolahan Kopra & $8.310 .393,26$ \\
\hline Total &
\end{tabular}

Sumber : diolah dari data primer, 2018

Tabel 10 menunjukkan bahwa rata-rata biaya tenaga kerja yang dikeluarkan oleh petani penghasil Kopra di Kecamatan Tomohon Barat yaitu sejumlah Rp 8.310.393,26. Rata-rata biaya tenaga kerja pada kegiatan panen (panjat, pengupasan, dan pengangkutan) yaitu sejumlah $\mathrm{Rp} 2.177 .808,89$ dan pada kegiatan pengolahan Kopra yaitu sejumlah Rp 6.132.584,27.

\section{Peralatan Pengolahan Kopra}

Rata-rata jumlah peralatan yang digunakan oleh petani penghasil Kopra di Kecamatan Tomohon Barat dapat dilihat pada Tabel 11.

Tabel 11. Rata-Rata Jumlah Peralatan yang Digunakan oleh Petani Penghasil Kopra di Kecamatan Tomohon Barat

\begin{tabular}{|c|c|}
\hline Peralatan & Rata-rata \\
\hline - Parang & 7,54 \\
\hline $\begin{array}{l}\text { - Pengupas serabut kelapa } \\
\text { (lewang) }\end{array}$ & 4,56 \\
\hline $\begin{array}{l}\text { - Pengupas daging kelapa } \\
\text { (pisau cungkil) }\end{array}$ & 4,28 \\
\hline Total & 16,38 \\
\hline
\end{tabular}


Tabel 11 menunjukkan rata-rata jumlah peralatan yang digunakan oleh petani penghasil Kopra di Kecamatan Tomohon Barat yaitu 16,38 unit yang terdiri atas alat peda (parang) sebanyak 7,54 unit, alat pengupas serabut kelapa (lewang) sebanyak 4,56 unit, dan alat pengupas daging kelapa (pisau cungkil) sebanyak 4,28 unit.

Tabel 12. Rata-Rata Biaya Peralatan yang Digunakan oleh Petani Penghasil Kopra di Kecamatan Tomohon Barat

\begin{tabular}{lcc}
\hline \multicolumn{1}{c}{ Peralatan } & Rata-rata & Persentase \\
\hline - Parang & $1.357 .078,65$ & 80,20 \\
- Pengupas serabut & $228.089,89$ & 13,48 \\
kelapa (lewang) & & \\
- Pengupas daging & $107.022,03$ & 6,32 \\
$\begin{array}{l}\text { kelapa (pisau } \\
\text { cungkil) }\end{array}$ & & \\
\hline \multicolumn{1}{c}{ Total } & $1.692 .191,01$ & 100,00 \\
\hline
\end{tabular}

Sumber : diolah dari data primer, 2018

Tabel 12 menunjukkan bahwa rata-rata total biaya peralatan pada petani penghasil Kopra yaitu sebesar Rp 1.692.191,01. Kontribusi terbesar berasal dari biaya peralatan parang yaitu sebesar Rp 1.357.078,65 atau sekitar 80\%. Diikuti alat lewang sebesar Rp 228.089,89 atau sekitar $13,48 \%$. Peralatan usahatani yang memberikan kontribusi terendah yaitu alat pisau cungkil yaitu sebesar Rp. 107.022,03 atau 6,32\%.

\section{Faktor - faktor yang Mempengaruhi Produksi Kopra}

a. Hasil Analisis Fungsi Produksi CobbDouglas

Analisis fungsi produksi Cobb Douglas dilakukan untuk mengetahui seberapa besar pengaruh dari masing-masing faktor produksi sebagai variabel bebas terhadap hasil produksi Kopra sebagai variabel terikat.

Berdasarkan analisis yang dilakukan dengan menggunakan aplikasi SPSS, maka analisis regresi terhadap model estimasi yang digunakan dalam penelitian ini diperoleh hasil yang terangkum pada Tabel 13.
Tabel 13. Hasil Analisis Regresi Faktor-Faktor yang Mempengaruhi Produksi Kopra di Kecamatan

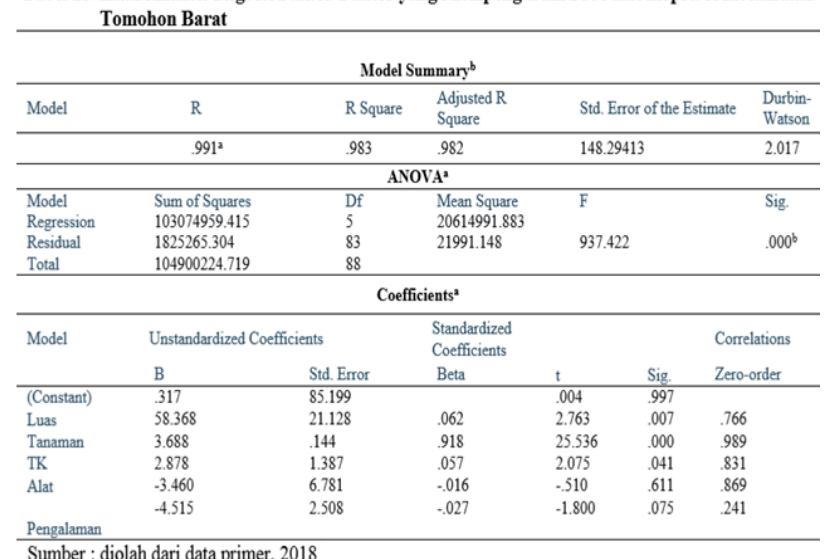

Berdasarkan hasil estimasi diatas, maka fungsi produksi Kopra diduga sebagai berikut :

LnProd.Kopra $=0,317+58,368$ LnLuas + 3,688LnTanaman $+2,878 \mathrm{LnTK}-3,460$ LnAlat - 4,515Ln Pengalaman

a. Uji Asumsi Klasik

- Uji Normalitas Data

Kenormalan suatu data penelitian merupakan syarat wajib yang harus terpenuhi dalam model regresi linier, sehingga perlu dilakukan uji normalitas untuk menguji apakah variabel terikat dan bebas berdistribusi normal atau tidak.

Uji normalitas dilakukan melalui pengujian normal probability plots atau Histogram yang dapat dilihat pada Gambar 2.

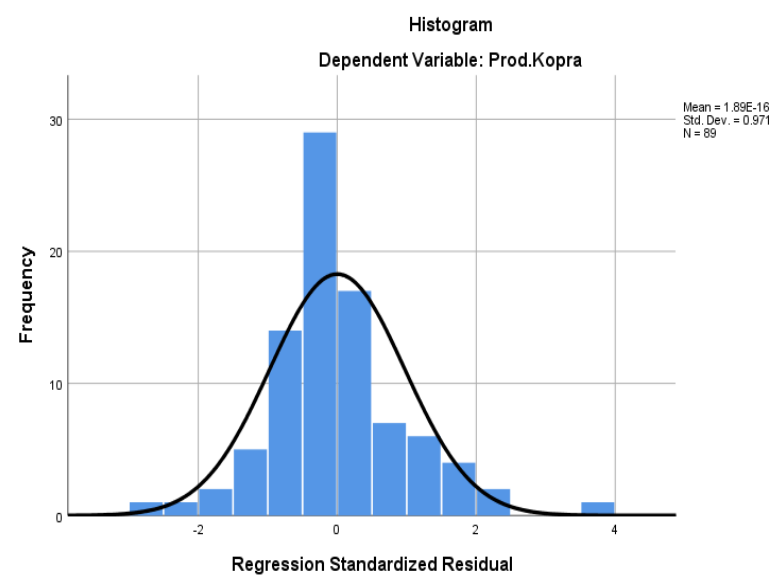

Gambar 2. Hasil Uji Normalitas Model Regresi FaktorFaktor yangMempengaruhi Produksi Kopra 
Gambar 2 menunjukkan bahwa pada normal probability plots titik-titik pada grafik (data) menyebar di sekitar garis diagonal, selain itu penyebarannya mengikuti garis diagonal, dan pada histogram terlihat garis melengkung ke atas membentuk gunung dengan kaki yang simetris, maka dapat disimpulkan bahwa data dalam penelitian berdistribusi normal. Hal ini menandakan data memiliki pola distribusi normal, sehingga dapat disimpulkan model fungsi produksi Kopra layak dipakai untuk menganalisa faktor-faktor yang mem pengaruhi produksi Kopra di Kecamatan Tomohon Barat.

\section{- Uji Multikoliniearitas}

Model regresi yang memenuhi kriteria BLUE, diantaranya adalah tidak terdapat korelasi antara variabel bebas. Oleh karena itu, perlu dilakukan uji multikolinieritas untuk mendeteksi apakah variabel bebas pada model regresi saling berkorelasi, yaitu dengan cara melihat nilai tolerance value atau Variance Inflation Factor (VIF).

Hasil deteksi multikolinieritas antar variabel bebas dalam analisis regresi faktorfaktor yang mempengaruhi produksi Kopra dapat dilihat pada Tabel 14.

Tabel 14. produksi Kopra

\begin{tabular}{|c|c|c|c|c|}
\hline \multicolumn{5}{|c|}{ Coefficients } \\
\hline \multirow[t]{2}{*}{ Model } & \multicolumn{4}{|c|}{ Correlations - - - } \\
\hline & Partial & Part & Tolerance & VIF \\
\hline (Constant) & & & I & \\
\hline Luas & .290 & .040 & .412 & $2.42 \%$ \\
\hline Tanaman & .942 & .370 & । .162 & 6.167 \\
\hline TK & .222 & .030 & $\checkmark .278$ & 3.598 \\
\hline Alat & -.056 & -.007 & $.201-$ & 4.973 \\
\hline Pengalaman & -.194 & -.026 & .904 & 1.107 \\
\hline
\end{tabular}

Tabel 14 menunjukkan bahwa semua nilai koefisien korelasi antar variabel bebas lebih dari 0,1 atau Variance Inflation Factor (VIF) kurang dari 10 (lihat yang dilingkari putus-putus merah). Hal ini menandakan model fungsi produksi Kopra tidak terjadi gejala multikolinieritas, sehingga layak dipakai untuk menganalisa faktor-faktor yang mempengaruhi produksi Kopra di Kecamatan Tomohon.

- Uji Heteroskedastisitas

Model regresi yang baik harus memiliki variance yang sama (homoskedastisitas), sehingga perlu dilakukan deteksi gejala ketidaksamaan variance dari residual satu pengamatan ke pengamatan lain melalui uji heteroskedastisitas. Pengujian gejala heteroskedastisitas dapat menggunakan grafik plot (scatter plot) antara nilai prediksi variabel terikat (ZPRED) dengan residualnya (SRESID) atau dengan cara uji Park.

Hasil deteksi gejala heteroskedastisitas dalam analisis regresi faktor-faktor yang mempengaruhi produksi Kopra dapat dilihat pada Gambar 3.

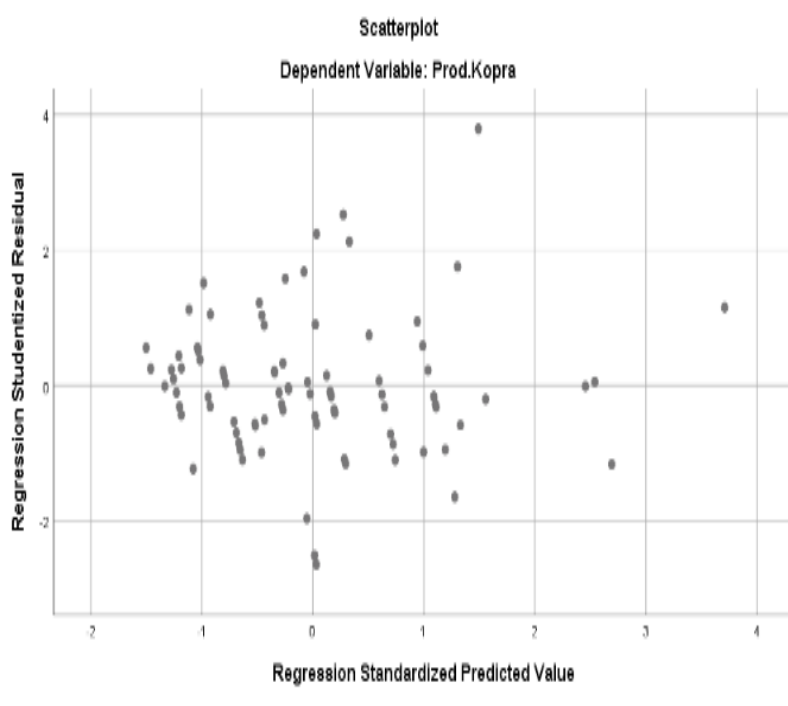

Gambar 3. Hasil Uji Heteroskedastisitas Model Regresi FaktorFaktor yang Mempengaruhi Produksi Kopra

Gambar 3 menunjukkan bahwa sebaran titik-titik residual pada grafik tidak teratur dan tidak membentuk suatu pola tertentu yang jelas, serta menyebar diatas maupun dibawah angka 0 pada sumbu Y. Hal ini berarti tidak terjadi masalah heteroskedastisitas pada model fungsi produksi Kopra, sehingga layak dipakai untuk menganalisa faktor-faktor yang mem pengaruhi produksi Kopra di Kecamatan Tomohon. 


\section{b. Uji Statistik}

- Koefisien Determinasi $\left(\mathrm{R}^{2}\right)$

Model fungsi produksi Kopra menunjukkan hubungan antara faktor produksi luas tanam, populasi tanaman, tenaga kerja, peralatan dan pengalaman dengan hasil produksi Kopra, yang menghasilkan koefisien determinasi $\left(\mathrm{R}^{2}\right)$ sebesar 0.983. Hal tersebut menandakan bahwa 98,3\% variasi produksi Kopra dapat dijelaskan oleh variasi penggunaan luas tanam, populasi tanaman, tenaga kerja, peralatan dan pengalaman. Sisanya yaitu $1,7 \%$ disebabkan oleh faktor lain yang tidak dimasukkan dalam model.

- Uji F

Berdasarkan hasil estimasi pada Tabel 14, diperoleh hasil uji $\mathrm{F}_{\text {hitung }}$ lebih besar dari $\mathrm{F}_{\text {tabel }}(937,422>2,32)$, sehingga $\mathrm{H}_{1}$ diterima dan $\mathrm{H}_{0}$ ditolak artinya secara bersama-sama variabel bebas berpengaruh nyata terhadap variabel terikat. Hal ini dapat disimpulkan bahwa secara bersamasama penggunaan faktor produksi luas tanam, populasi tanaman, curahan tenaga kerja, peralatan dan pengalaman mempunyai pengaruh yang nyata terhadap produksi Kopra.

\section{- Uji T}

Secara parsial untuk melihat pengaruh dari masing-masing faktor produksi yang diamati dari penelitian ini digunakan uji T. Hasil uji $\mathrm{T}$ yang terangkum pada Tabel 14 menunjukkan bahwa variabel luas tanam dan populasi tanaman berpengaruh nyata terhadap produksi Kopra pada taraf kepercayaan 99\%, sedangkan tenaga kerja berpengaruh nyata terhadap produksi Kopra pada taraf kepercayaan 95\%. Variabel peralatan dan pengalaman tidak berpengaruh terhadap produksi Kopra. Hal ini menunjukan bahwa peluang untuk meningkatkan produksi terletak pada tiga faktor produksi yaitu luas tanam, populasi tanaman, dan tenaga kerja.

\section{c. Elastisitas Faktor-Faktor Produksi Kopra}

Soekartawi (1991) mengungkapkan bahwa hasil pendugaan melalui fungsi produksi Cobb-Douglass akan menghasilkan koefisien regresi sekaligus menunjukkan besaran elastisitas produksi (Ep). Besaran elastisitas masing-masing faktor produksi pada fungsi produksi Kopra terangkum pada Tabel 15.
Tabel 15. Nilai Elastisitas Faktor-Faktor Produksi pada Fungsi Produksi Kopra

\begin{tabular}{lc}
\hline Faktor Produksi & $\begin{array}{c}\text { Nilai Elastisitas } \\
\text { Produksi (Ep) }\end{array}$ \\
\hline Luas Tanam & 58.368 \\
Populasi Tanaman & 3.688 \\
Curahan Tenaga & 2.878 \\
Kerja & \\
Jumlah Peralatan & -3.460 \\
Pengalaman & -4.515 \\
\hline
\end{tabular}

Sumber : diolah dari data primer, 2018

Tabel 15 menunjukkan bahwa elastisitas produksi pada faktor produksi luas tanam, populasi tanaman, dan tenaga kerja bernilai positif. Nilai Ep yang bertanda positif tersebut, menandakan setiap penambahan faktor produksi luas tanam, populasi tanaman, dan tenaga kerjaakan memberikan tambahan produksi Kopra. Sebaliknya, variabel peralatan dan pengalaman yang menghasilkan Ep bernilai negatif, menandakan bahwa penambahan faktor produksi pengalaman akan berakibat penurunan produksi Kopra.

\section{Skala Hasil Usaha}

Skala hasil usaha menunjukkan tanggapan hasil produksi terhadap perubahan faktor-faktor produksi, yang terbagi atas : skala hasil yang naik, turun atau konstan. Skala hasil usaha dapat diketahui dengan cara menjumlahkan koefisien elastisitas dari masing-masing faktor produksi.

Jika hasil penjumlahan semua koefisien regesi tersebut kurang dari satu, maka penambahan faktor produksi dalam jumlah yang sama akan menyebabkan penurunan tambahan hasil produksi. Jika hasil penambahan semua koefisien regresi lebih dari satu, maka penambahan faktor produksi dalam jumlah yang sama akan menyebabkan kenaikan dari tambahan hasil produksi. Dan jika penambahan semua koefisien tersebut sama dengan satu maka penambahan faktor produksi dalam jumlah yang sama tidak akan berpengaruh terhadap hasil produksi, karena tambahan hasil produksi adalah tetap. 
Hasil analisis regresi diperoleh koefisien regresi sekaligus elastisitas faktor produksi luas tanam $\beta_{1}=58,368$, populasi tanaman $\beta 2=3,688$, curahan tenaga kerja $\beta 3$ $=2,878$, jumlah peralatan $\beta 4=-3,46$ dan pengalaman $\beta 5=-4,515$. Penjumlahan dari seluruh koefisien masing-masing faktor produksi menghasilkan nilai 65,959 . Hasil penjumlahan tersebut menunjukkan nilai yang lebih dari satu, sehingga skala hasil produksi Kopra termasuk dalam increasing return to scale, yang berarti bahwa setiap penambahan input $1 \%$ akan meningkatkan produksi lebih dari $1 \%$.

\section{KESIMPULAN DAN SARAN}

\section{Kesimpulan}

1. a. Faktor - faktor produksi luas tanam, populasi tanaman, curahan tenaga kerja, jumlah peralatan, dan pengalaman yang digunakan oleh petani penghasil Kopra di Kecamatan Tomohon Barat secara bersama-sama mempengaruhi produksi Kopra. Secara terpisah faktor produksi luas tanam, populasi tanaman, dan tenaga kerja berpengaruh nyata dan positif terhadap produksi Kopra.

b. Skala hasil produksi Kopra di Kecamatan Tomohon Barat menunjukkan increasing return to scale, yang berarti petani masih mampu memperoleh produksi yang menguntungkan dari sejumlah faktor produksi yang ditambahkan.

2. Tingkat elastisitas faktor produksi luas tanam, populasi tanaman, dan tenaga kerja di Kecamatan Tomohon Barat menunjukkan bernilai positif dan lebih dari satu. Ini menandakan penggunaan faktor produksi belum efisien, karena belum mencapai keuntungan maksimum. Setiap penambahan faktor produksi tersebut mengakibatkan kenaikan produksi Kopra yang terus bertambah. Sedangkan penggunaan faktor produksi peralatan dan pengalaman menunjukkan bernilai negatif. Ini menandakan penggunaan faktor produksi tidak efisien (irrasional), karena produksi yang diperoleh akan menghasilkan Kopra yang lebih sedikit dari penggunaan faktor produksi yang lebih banyak.

\section{Saran}

1. Petani penghasil Kopra disarankan masih memungkinkan menambah penggunaan faktor produksi, karena masih memungkinkan untuk meningkatkan produksi Kopra.

2. Perlu dilakukan penelitian lanjutan terutama mengenai efisiensi penggunaan faktor-faktor produksi.

\section{DAFTAR PUSTAKA}

Adisetiawan, 2011. Keseimbangan Jangka Panjang Antara Variabel Makro Ekonomi dengan Indeks Harga Saham.Trikonomika, Vol. 10, No.2, Desember 2011. Badan Pusat Statistik (BPS) Provinsi Sulawesi Utara. 2017. Data Tingkat Kemiskinan.

Everet dan Ebert, 1992. Production and Operation Management; Concept, Models And Behavior. Edisi 10. New Jersy : Prentice Hall.Inc..

Imam, Ghozali, 2005. Aplikasi Analisis Multivariat dengan Program SPSS.Edisi 3. UNDIP. Semarang.

Joesran dan Fathorozi, 2003. Teori Ekonomi Mikro dilengkapi beberapa Bentuk Fungsi produksi. Salemba Empat. Jakarta.

Mudrajat, Kuncoro, 2013. Metode Riset untuk Bisnis dan Ekonomi. Edisi Keempat. Erlangga. Jakarta. 
Walter, Nicholson, 2002. Microeconomic Theory. Halsted Press Book Water 100 Ontario. 